\title{
EFFECT OF ZINC OR/AND MANGANESE METHIONINE SUPPLEMENTS ON PERFORMANCE OF LACTATING BUFFALOES . \\ Shakweer,I.M.E. ${ }^{*}$; G.M. Mustafa**; G.A. Ahmed** and M.I.N. Ismail ${ }^{\star}$ \\ ${ }^{*}$ Animal Production Research Institute, Agric. Res. Center \\ ${ }^{\star \star}$ Faculty of Agriculture, Fayoum University.
}

\begin{abstract}
This study was conducted to investigate the effect of adding chelated zinc methionine or / and manganese methionine on the digestibility coefficients, nutritive value, some ruminal and blood parameters, milk yield and composition of lactating buffaloes.. Sixteen lactating buffaloes at the last three months of pregnancy were divided into four similar groups. Animals were fed according to Ghoneim (1964) Feeding standard. The lactating buffaloes were fed on the following rations: The control group was fed concentrate feed mixture, berseem hay (Trifolium alexandrinum) and rice straw without minerals supplementation. The $1^{\text {st }}$ tested group was fed the control ration $+40 \mathrm{mg}$ zinc methionine $/ \mathrm{kg} \mathrm{DMI})$. The $2^{\text {nd }}$ tested group was fed control ration $+40 \mathrm{mg}$ manganese methionine $/ \mathrm{kg} \mathrm{DMI})$. The $3^{\text {rd }}$ group was fed the control ration $+40 \mathrm{mg}$ zinc methionine $+40 \mathrm{mg}$ manganese methionine $/ \mathrm{kg}$ DMl). All groups were fed from about three months before the expected calving date up to 105 days of lactation. Results indicated that the addition of both chelated zinc and manganese methionine improved DM, OM, CP, CF, EE and NFE digestibilities and feeding values (TDN and DCP). Also, chelated zinc, manganese and zinc plus manganese supplements tended to reduce ammonia $-\mathrm{N}$,but increase TVFA's, improved feed conversion and increase milk yield. Moreover, chelated zinc methionine and manganese methionine supplementation increase serum total protein, albumin and globulin, but reduced the concentration of urea in blood serum. From the obtained results. It could be concluded that Zn-Met plus Mn-Met supplementation could be economically and successfully used for lactating buffaloes to improve digestibility's, feeding values, feed efficiency, milk production and economical efficiency .
\end{abstract}

Keywords: Lactating buffaloes - zinc - manganese - feed intake - digestibility ruminal and blood parameters - milk yield and composition.

\section{INTRODUCTION}

Heavy metal salts have been used routinely to precipitate soluble proteins in laboratory procedures (Cohn et al., 1950). The mechanism involves a crosslinking of peptide as metal ions bind with sulfhydryl groups (Haurowitz, 1950). The use of amino acid complex minerals in mineral supplements compared to inorganic forms is still controversial. Limited research has been done concerning the biological availability of organic and inorganic mineral sources. The majority of bioavailable zinc when supplemented in relatively high levels is stored in body organs such as liver, kidney and pancreas with minor storage in bone, muscle and skin (Ott et al., 1966). Zinc is known to be essential for the function and /or structure of several enzymes as dehydrogenases, peptidases, phosphatases, atransphosphorylase, carboxypeptidase and it was found to be an essential 
component of both DNA and RNA polymerases (Miles and Henry, 1999). It is also vital for a variety of hormonal activities including growth hormone, glucagons, insulin, as well as sex hormones. Manganese is an important trace mineral in biological systems, acting as an enzyme component and activator (Leach and Harris, 1997).

Manganese is poorly absorbed (1\% or lees) from ruminant diet (Bruwaene et al., 1984). Dietary factors that may influence manganese bioavailability have received little attention, probably because manganese deficiency is not considered to be a major problem in ruminants. Limited evidence suggests that high dietary calcium and phosphorus may reduce manganese bioavailability (Hidiroglow, 1979). It has been suggested that manganese may act as a cofactor for mevalonate kinase and faresyl pyrophosphate synthase, enzymeo involved in the production of squalene, aprecursor of cholesterol (Curran and Azarnoff, 1961 and Davis et al., 1990). Many studies have shown improved growth, milk yield, reproductive performance and/ or immune respone in ruminants fed diets containing organic trace mineral (Spears 1996; Socha and Johanson, 1998 and Gunter et al., 1999). Studies with pregnant cows had found that zinc deficiency would lead the offspring to be born with gross congenital malformation of the body. Zinc has been shown to reduce ruminal degradability of feed protein and diets that contain soya protein treated with zinc and promotes greater quantities of ruminal escape protein (Kincaid et al., 1997). The depression in urea degradadation is greater with supplemental zinc than that with supplemental manganese (Arelovich, 1998). Improved bioavailability of zinc methionine may stimulate weight gain and feed conversion ratio in cattle (Kessler et al., 2003).

The objective of this study was to investigate the effect of zincmethionine or/and manganese-methionine supplementation on digestibility, rumen fermentation, blood plasma constituents, milk yield and composition of lactating buffaloes.

\section{MATERIALS AND METHODS}

This study was carried out at the Animal Production Research Station of Sids, Animal Production Research Institute, Agricultural Research Center, Ministry of Agriculture, Egypt. The experiment was planned to investigate the effect of Zinc or / and Manganese methionine supplementation on productive performance, milk yield, milk composition, digestion coefficients, rumen parameters and blood parameters of lactating buffaloes. Sixteen lactating buffaloes in at the last three months of pregnancy were divided into four similar groups (four animals each) balanced for live body weight, milk yield and age. The lactating buffaloes were fed on the following rations. The control group was fed concentrate feed mixture (CFM) + berseem hay + rice straw) without supplementation. The $1^{\text {st }}$ tested group was fed control ration $+40 \mathrm{mg}$ zinc methionine $/ \mathrm{kg} \mathrm{DMl}$. The $2^{\text {nd }}$ tested group was fed control ration $+40 \mathrm{mg}$ manganese methionine $/ \mathrm{kg} \mathrm{DMI}$. The $3^{\text {rd }}$ tested group was fed control ration + 40mg zinc + 40mg manganese methionine $/ \mathrm{kg}$ DMl according to Ghoneim (1964) feeding standard. Feed additives zinc methionine ( Biomet 
$\mathrm{Zn}$ as commercial name ) contained (10\% zinc sulfate, $13.4 \%$ protein, $22.8 \%$ methionine, and $60 \%$ ash) while manganese methionine (Bioplex $\mathrm{Mn}$ as commercial name) contained (10\% manganese sulfate , $15.9 \%$ protein, $27.2 \%$ methionine, and $60 \%$ ash). They were mixed manually with some ground amounts of CFM. Feeding experiments was started for three month before the expected calving date and continued up to 105 days of lactation period. Each group was given (during prepartum) a maintenance ration plus productive requirements which can cover and equivalent to produce $2 \mathrm{~kg}$ milk yield with $7 \%$ fat. After parturition buffaloes were fed according to Ghoneim(1964) feeding standard. Buffaloes were hand milked twice daily ( $6.0 \mathrm{am}$ and $5.0 \mathrm{pm}$ ) during the experimental period (105 days) while milk yields were recorded individually for each milking. Actual milk yield was converted into $7 \%$ FCM using the formula given by Reafat and Saleh, (1962) as follows: $7 \% \mathrm{FCM}=0.265$ milk yield +10.5 Fat yields. Feed conversion was calculated as the amount of DM, TDN and DCP required for $1 \mathrm{~kg}$ of $7 \%$ FCM . Milk samples were collected individually twice every week; samples of milk were used to determine protein, fat, total solids and ash contents. Fat percentage in milk was determined by the standard Gerber's method described by Ling, (1963). Four digestibility trials were carried out at the end of the feeding trial for four days using three buffaloes from each group to determine the nutrient digestibilities and nutritive value of the experimental rations using acid insoluble ash (AIA ) technique according to Van Keulen and Young (1977). Faces samples were daily collected from the rectum for four successive days from each animal . Chemical composition of the feed and feces samples were analyzed according to A.O.A.C. (1995) procedures . Rumen liquor samples were collected by stomach tube at three times ( just before morning feeding, 3.00 and $6.00 \mathrm{hrs}$ after feeding ). Samples were strained through four folds of cheese cloth. Ruminal $\mathrm{pH}$ was determined immediately using a digital $\mathrm{pH}$ meter. Ammonia- $\mathrm{N}$ was determined according to the modified semi-micro kijeldehl digestion method A.O.A,C. (1995). Total volatile fatty acids (TVFA's) was determined according to Eadie,et al.,(1967). Blood samples were taken from three buffaloes from each group at the end of the collection period before feeding from the jugular vein and allowed to flow into acid washed heparinzied tubes. Blood samples were centrifuged immediately at $4000 \mathrm{rpm}$ for 20 minuets. Blood plasma was used for determination of total protein, albumin, urea, and zinc content . Total protein was determined according to Weichselboum (1946). Albumin was determined colorimetrically according to Drupt (1974). Urea was determined according to Fawcett and Scott (1960). Zinc was determined according to Makino et al. (1982). The Economic efficiency (\%) was calculated as a percentage of price of daily milk yield (L.E) to average daily feed cost (L.E.).

The obtained data were statistically analyzed by general linear, model using ANOVA procedures of SAS (1985). The significant differences among means of treatments were tested using Duncan multiple range test (Duncan 1955). 


\section{RESULTS AND DISCUSSION}

\section{Chemical composition of feedstuffs}

Data of table (1) show that the chemical composition of the ingredients used to formulate the experimental rations were within the normal values published by A.P.R.I. (1997).

Table (1): Chemical composition of tested feedstuffs and calculated composition of experimental rations:

\begin{tabular}{|lc|cccccc|}
\hline \multicolumn{1}{|c}{ Item } & DM & OM & CP & EE & CF & NFE & Ash \\
\hline CF M $^{*}$ & 90.95 & 92.70 & 16.51 & 3.10 & 12.74 & 60.35 & 7.30 \\
Berseem hay (3 ${ }^{\text {rd }}$ cut) & 89.40 & 88.18 & 12.40 & 2.32 & 27.82 & 45.64 & 11.82 \\
Rice straw & 91.00 & 84.10 & 3.05 & 1.91 & 37.72 & 41.42 & 15.90 \\
Calculated experimental rations: & & & & & & \\
Ration 1 (control) & 90.52 & 88.94 & 11.47 & 2.53 & 24.21 & 50.73 & 11.06 \\
Ration 2 & 90.54 & 88.94 & 11.47 & 2.54 & 24.25 & 50.68 & 11.06 \\
Ration 3 & 90.54 & 88.94 & 11.47 & 2.54 & 24.25 & 50.68 & 11.06 \\
Ration 4 & 90.51 & 88.95 & 11.49 & 2.54 & 24.18 & 50.74 & 11.05 \\
\hline
\end{tabular}

* Concentrate feed Mixture contained: $30 \%$ yellow corn, $42 \%$ undecorticated cotton seed meal, $20 \%$ wheat bran, $5 \%$ molasses, $2 \%$ limestone, $1 \%$ common salt

\section{Nutrient digestibitities and feeding values}

Results of digestibility and nutritive values are presented in table (2) Addition of Zn-Met plus Mn-Met significantly $(p<0.05)$ increased the digestion coefficients of OM,CP,EE,CF and NFE than those of Mn-Met, Zn-Met supplementation and control group. While the differences of the digestion coefficients of DM were insignificant among zinc-Met or Mn-Met and ZnMet plus Mn-Met supplemented groups. The digestion coefficients of DM , EE and NFE showed insignificant differences between the Zn-Met and MnMet supplemented groups The digestion coefficient of OM, CP and CF of $\mathrm{Zn}$-Met supplemented group was significantly $(\mathrm{p}<0.05)$ higher than that of Mn-Met addition group. Zn-Met or Zn-Met plus Mn-Met supplementation significantly $(p<0.05)$ increased the digestibility coefficients of CP compared to the Mn-Met supplementation and control group. The higher apparent digestibility coefficient with zinc supplemented rations may be due to the improvement of their absorption.

These results are in line with those obtained by Mousa and EL-Sheikh, (2004) who found that the apparent digestibility of DM,OM,CP,CF;EE and NFE were slightly increased by different levels of zinc sulfate supplementation to the ration of lactating buffaloes . Shakweer et al., (2005), Shakweer and El-Nahas, (2005) and Shakweer et al., (2006) found that the addition of different levels of zinc methionine to the ration of Friesian dairy cows, suckling calves and Friesian growing calves increased the digestibilities of DM, OM,CP and CF compared with those of the control group. Basiuoni et al, (2009) found that the apparent digestibility of DM, OM, $\mathrm{CP}, \mathrm{CF}, \mathrm{EE}$ and NFE were significantly increased by different levels $(5 \mathrm{~g}$ or 10 $\mathrm{g} / \mathrm{head} /$ day) of $\mathrm{Zn}$-Met supplementation to the ration of lactating Frisian cows. 
Table (2): Effect of zinc or/and manganese methionine supplementation on nutrients digestibility and nutritive values by lactating buffaloes:

\begin{tabular}{|c|c|c|c|c|c|}
\hline \multirow[b]{2}{*}{ Items } & \multicolumn{4}{|c|}{ Experimental groups } & \multirow[b]{2}{*}{$\begin{array}{l}\text { SE } \\
\pm\end{array}$} \\
\hline & Control & $\begin{array}{c}40 \mathrm{mg} \\
\text { Zn-Met/ kg DMI }\end{array}$ & $\begin{array}{c}40 \mathrm{mg} \\
\text { Mn-Met / kg DMI }\end{array}$ & $\begin{array}{c}40 \mathrm{mg} \mathrm{Zn-Met} \mathrm{+} \\
40 \mathrm{mg} \text { Mn-Met / kg DMI }\end{array}$ & \\
\hline \multicolumn{3}{|c|}{ Digestibility coefficients \% } & & & \\
\hline DM & $65.25^{\mathrm{b}}$ & $69.3^{\mathrm{a}}$ & $68.8^{\mathrm{a}}$ & $70.19^{a}$ & 0.60 \\
\hline OM & $68.66^{\mathrm{d}}$ & $71.64^{\mathrm{b}}$ & $70.34^{\mathrm{c}}$ & $73.13^{\mathrm{a}}$ & 0.51 \\
\hline CP & $62.82^{\mathrm{d}}$ & $73.09^{b}$ & $68.28^{\mathrm{C}}$ & $74.93^{\mathrm{a}}$ & 0.42 \\
\hline EE & $68.57^{\mathrm{b}}$ & $69.17^{b}$ & $68.83^{\mathrm{b}}$ & $70.22^{a}$ & 0.23 \\
\hline CF & $62.84^{\mathrm{d}}$ & $65.39^{\mathrm{b}}$ & $63.70^{\mathrm{C}}$ & $68.19^{a}$ & 0.62 \\
\hline NFE & $74.10^{c}$ & $75.50^{\mathrm{b}}$ & $75.34^{\mathrm{b}}$ & $76.11^{a}$ & 0.23 \\
\hline \multicolumn{6}{|c|}{ Nutritive value \% } \\
\hline TDN & $63.93^{d}$ & $65.73^{b}$ & $64.68^{\mathrm{C}}$ & $66.96^{a}$ & 0.25 \\
\hline DCP & $7.21^{d}$ & $8.38^{\mathrm{b}}$ & $7.83^{c}$ & $8.61^{a}$ & 0.31 \\
\hline
\end{tabular}

a, b, c and d: values in the some row with different superscripts differ significantly $(P \leq 0.05)$.

The nutritive values as TDN and DCP were significantly $(p<0.05)$ higher for $\mathrm{Zn}$-Met plus Mn-Met addition than those of the other treatments. While the $\mathrm{Zn}$-Met supplementation significantly increased DCP than those of the Mn-Met addition. These results are in agreement with those obtained by Shakweer et al., (2005) and Shakweer et al., (2006) who found that TDN and DCP were significantly $(p<0.05)$ increased by different levels of zinc methionine supplementation to the ration of lactating Frisian cows and growing Friesian calves. Mousa and EL-Sheikh, (2004) found that TDN and DCP were significantly $(P<0.05)$ increased by the addition of the highest level of zinc sulfate. Basiuoni et al, (2009) found that TDN and DCP were significantly $(p<0.05)$ increased by different levels of $Z n-M e t$ supplementation to the ration of lactating Frisian cows . Mandal et al., (2007) found that $\mathrm{Zn}$ supplementation ( 20 or $135 \mathrm{mg} / \mathrm{kg} \mathrm{DMI}$ ) had no effect on the digestibility of DM and CP. The improvement in digestibility coefficients could be illustrated on the basis that zinc or/ and manganese methionine can play indirect role to stimulate anaerobic fermentation of organic matter that improve the utilization efficiency of nutrients and direct role to improve digestion in abomasums.

\section{Ruminal parameters:}

Results obtained in table (3) reveled the minimum $\mathrm{pH}$ values were observed at $3 \mathrm{hrs}$ post feeding and tended to increase after $6 \mathrm{hrs}$. This trend was observed with control group and Mn-Met addition while the opposite trend was showen with $\mathrm{Mn}$-Met and $\mathrm{Zn}$-Met plus Mn-Met supplemented group. These results are in hormony with those found by Shakweer et al., (2005) and Shakweer et al., (2006) who found that the average $\mathrm{pH}$ values were not affected by the different levels $(40,80,120 \mathrm{mg} / \mathrm{kg} \mathrm{DMI})$ of zinc methionine supplementation to the ration of the lactating Friesian cows and growing Friesian calves. On the other hand, Basiuoni et al, (2009) found that the mean of rumen $\mathrm{pH}$ value slightly decreased with $\mathrm{Zn}$-Met supplementation 
groups than control with different levels $(5 \mathrm{~g}, 10 \mathrm{~g}$ ) of $\mathrm{Zn}$-Met supplementation to the ration of lactating Friesian cows. The maximum $\mathrm{NH}_{3}-\mathrm{N}$ values were observed at $3 \mathrm{hrs}$ post feeding and tended to decrease at $6 \mathrm{hrs}$. The trend was observed with all supplemented groups and control group. Ammonia-N values at 3 hrs post feeding was significantly higher for control group than those for all supplementation group, but the lowest values were those for the $\mathrm{Zn}-$ Met plus Mn-Met or $\mathrm{Zn}$-Met groups. The decrease ruminal ammonia $-\mathrm{N}$ concentration with Zn-met, Mn-Met and Zn-Met plus Mn-Met supplementation may be due to improve the rumen microbes activity utilizing Ammonia-N to produce microbial protein. These results are in line with those obtained by Basiuoni et al, (2009) who found that the rumen $\mathrm{NH}_{3}-\mathrm{N}$ concentration was reduced $(p<0.05)$ with different levels $(5 \mathrm{~g}$ or $10 \mathrm{~g})$ of zinc methionine supplementation compared to the control group of lactating Friesian cows. Shakweer et al., (2005) and Shakweer et al., (2006) found that the ammonia$\mathrm{N}$ in ruminal fluid was decreased with different levels of zinc methionine compared with that of the control group at $3 \mathrm{hr}$ post feeding of the growing Friesian calves .

Table (3): Effect of zinc or/and manganese methionine supplementation and sampling time on ruminal $\mathrm{pH}$, ammonia- $\mathrm{N}$ and TVFA's concentration of lactating buffaloes

\begin{tabular}{|c|c|c|c|c|c|c|}
\hline \multirow[b]{2}{*}{ Parameter } & \multirow[b]{2}{*}{ Time } & \multicolumn{4}{|c|}{ Experimental groups } & \multirow[b]{2}{*}{$\begin{array}{c}\text { SE } \\
\pm\end{array}$} \\
\hline & & Control & $\begin{array}{l}40 \mathrm{mg} \mathrm{Zn-} \\
\text { Met/ kgDMI }\end{array}$ & $\begin{array}{l}40 \mathrm{mg} \mathrm{Mn-} \\
\text { Met / kgDMI }\end{array}$ & $\begin{array}{c}40 \text { mg Zn-Met + } \\
40 \text { mg Mn-Met / kgDMI }\end{array}$ & \\
\hline $\mathrm{pH}$ & $\begin{array}{l}0 \\
3 \\
6\end{array}$ & $\begin{array}{l}7.13 \\
6.57^{\mathrm{b}} \\
6.78^{\mathrm{a}}\end{array}$ & $\begin{array}{l}7.08 \\
6.71^{\mathrm{a}} \\
6.67^{\mathrm{ab}}\end{array}$ & $\begin{array}{c}7.10 \\
6.64^{\mathrm{ab}} \\
6.70^{\mathrm{ab}}\end{array}$ & $\begin{array}{l}7.11 \\
6.74^{\mathrm{a}} \\
6.59^{\mathrm{b}}\end{array}$ & $\begin{array}{l}0.01 \\
0.02 \\
0.03\end{array}$ \\
\hline $\begin{array}{l}\mathrm{NH}_{3}-\mathrm{N} \\
(\mathrm{mg} / 100 \mathrm{ml} \mathrm{RL})\end{array}$ & $\begin{array}{l}0 \\
3 \\
6\end{array}$ & $\begin{array}{c}19.20 \\
29.02^{\mathrm{a}} \\
24.40^{\mathrm{a}}\end{array}$ & $\begin{array}{c}18.72 \\
26.45^{b} \\
21.64^{b}\end{array}$ & $\begin{array}{c}19.12 \\
27.60^{\mathrm{ab}} \\
23.38^{\mathrm{a}}\end{array}$ & $\begin{array}{c}17.78 \\
25.94^{b} \\
20.29^{b}\end{array}$ & $\begin{array}{l}0.31 \\
0.42 \\
0.52\end{array}$ \\
\hline $\begin{array}{l}\text { TVFA's } \\
(\mathrm{meq} / 100 \mathrm{ml} \mathrm{RL})\end{array}$ & $\begin{array}{l}0 \\
3 \\
6\end{array}$ & $\begin{array}{l}6.53 \\
8.83 \\
6.26^{\mathrm{b}}\end{array}$ & $\begin{array}{c}6.92 \\
9.29 \\
6.94^{\mathrm{ab}}\end{array}$ & $\begin{array}{c}6.77 \\
9.09 \\
6.37^{\mathrm{ab}}\end{array}$ & $\begin{array}{l}7.07 \\
9.48 \\
7.15^{\mathrm{a}}\end{array}$ & $\begin{array}{l}0.20 \\
0.16 \\
0.15\end{array}$ \\
\hline
\end{tabular}

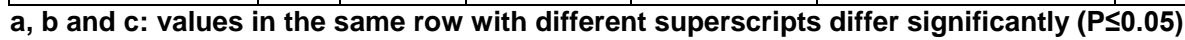

The level of ruminal total VFA's reached to maximum level at $3 \mathrm{hrs}$ post feeding and started to decrease afterwards. The trend was observed in all experimental groups. These results suggest that the anaerobic fermentation of protected amino acid were more efficient and faster yielding more total VFA's than control ration. These results in accordance with the finding of Basiuoni et al, (2009) who found that the concentrations of TVFA's in rumen liquor were significantly $(p<0.05)$ higher with different levels $(5 \mathrm{~g}, 10 \mathrm{~g})$ of zinc methionine supplementation than that of control group of lactating Frisian cows. Shakweer et al., (2005) and Shakweer et al., (2006) found that the TVFA's was increased with all different levels $(40,80,120 \mathrm{mg} / \mathrm{kg} \mathrm{DMI})$ of $\mathrm{Zn}$ Met supplementation compared with that of the control group. Spears et al., (2004) found that the Znic methionine addition increased molar proportion of propionate and reduced molar proportions of butyrate and valerate compared to the other treatments (ZnSO4 or ZnGly) and control group for steers. 


\section{Milk yield and composition:}

Addition of Zn-Met plus Mn-Met supplements significantly increased the actual and $7 \%$ fat corrected milk yield of lactating buffaloes compared to those the different groups. Also, supplemented groups apperent to higher miljk yield than those of control group. The increase in milk yield with Zn-Met plus Mn-Met , Mn-Met and Zn-Met supplementation may be due to one or more reasons, higher both of nutrients digestibility and TVFA's concentration and lower ammonia nitrogen concentration in the rumen. Also, apparent increase in the efficiency of nitrogen utilization as well as an increased conversion and availability of nutrients for milk synthesis. Addition of Zn-Met plus Mn-Met, Mn-Met and Zn-Met supplementation led to significant increase $(P<0.05)$ in milk fat yield, milk protein yield and yield of milk SNF . The increase of milk fat yield with Zn-Met supplementation may be due to that methionine in particular might facilitate the transfer of blood lipids to milk by furnishing methyl group for synthesis of choline and phosphatidylcholine, which represents an important link between methionine and lipid metabolism in ruminant ( Seymour et al., 1990). The increase in milk protein yield with Zn-Met supplementation may be due to milk protein response to post ruminal supply of limiting amino acids were much lower on low protein $(\leq 14 \% \mathrm{cp}$ ) compared with high protein rations ( Rulquin and Verite, 1993) .Also, higher DCP content with Zn-Met supplementation .

Table (4): Effect of zinc or/and manganese methionine supplementation on actual daily milk yield , $7 \%$ fat correct milk yield and milk composition of lactating buffaloes.

\begin{tabular}{|c|c|c|c|c|c|}
\hline & \multicolumn{4}{|c|}{ Experimental groups } & \multirow[b]{2}{*}{$\begin{array}{c}\text { SE } \\
\pm\end{array}$} \\
\hline & Control & $\begin{array}{c}40 \mathrm{mg} \\
\text { Zn-Met/ kgDMI }\end{array}$ & $\begin{array}{c}40 \mathrm{mg} \\
\text { Mn-Met / } \\
\text { kgDMI }\end{array}$ & $\begin{array}{c}40 \text { mg Zn-Met + } \\
40 \text { mg Mn-Met / } \\
\text { kgDMl }\end{array}$ & \\
\hline Daily milk yield, kg/day & $5.61^{c}$ & $6.84^{\mathrm{b}}$ & $7.16^{\mathrm{b}}$ & $7.89^{a}$ & 0.23 \\
\hline $7 \%$ fat correct milk yield , $\mathrm{kg} / \mathrm{day}$ & $5.43^{c}$ & $6.92^{b}$ & $7.09^{a b}$ & $7.78^{\mathrm{a}}$ & 0.24 \\
\hline \multicolumn{6}{|c|}{ Milk composition (\%) } \\
\hline Fat & 6.75 & 7.15 & 6.93 & 6.89 & - \\
\hline Protein & 4.39 & 4.58 & 4.56 & 4.66 & - \\
\hline Lactose & 4.34 & 4.35 & 4.31 & 4.33 & - \\
\hline Solids non fat & 10.12 & 10.20 & 10.17 & 10.25 & - \\
\hline
\end{tabular}

a, b and c: values in the some row with different superscripts differ significantly $(\mathrm{P} \leq 0.05)$.

These results are in line with those obtained by Basiuoni et al, (2009) who found that the different levels $(5 \mathrm{~g}$ or $10 \mathrm{~g}$ ) of zinc methionine supplementation significantly $(p<0.05)$ increased the actual milk yield, yield of milk fat, yield of milk protein and yield of milk SNF of Friesian cows compared to the control group. Mousa and EL-Sheikh, (2004) indicated that addition of 80 and $120 \mathrm{mg}$ zinc sulfate to ration did not affect actual milk yield and $7 \%$ fat corrected milk of lactating buffaloes. Compbell et al., (1999) and Salama et al., (2003) who reported that milk yield did not differ between treatment by zinc in lactating cows or goats . Shakweer et al., (2005) found 
that the different levels $(40,80,120 \mathrm{mg} / \mathrm{kg} \mathrm{DMI})$ of zinc methionine supplementation increased the actual milk yield and $4 \%$ fat corrected milk of dairy Friesian cows compared to the control group.

\section{Blood parameters}

The effect of Zn-Met , Mn-Met and Zn-Met plus Mn-Met supplementation on blood plasma constituents ( total protein , albumin , urea, zinc and manganese concentration ) of lactating buffaloes are shown in table (5). The $\mathrm{Zn}$-Met plus Mn-Met supplementation led to significant $(\mathrm{P}<0.05)$ increase in concentration of plasma total protein compared to other groups , while $\mathrm{Mn}$-Met addition had the lowest values. Concentration of plasma albumin significantly increased $(P<0.05)$ with $\mathrm{Zn}$-Met plus Mn-Met and $\mathrm{Zn}$ Met supplementation compared to that the Mn-Met and control group. Concentration of plasma globulin significantly $(P<0.05)$ increased with $Z n-M e t$ plus Mn-Met supplementation compared to that of Mn-Met, Zn-Met and control group. However, concentration of plasma urea significantly $(P<0.05)$ increased with control group compared to that of Zn-Met , Mn-Met supplementation, while Mn-Met addition had the lowest values compared to that of Zn-Met, Mn-Met supplementation and control group. The Zn-Met plus Mn-Met supplementation led to significant $(P<0.05)$ increase in zinc and manganese concentration in blood plasma compared to that of $\mathrm{Zn}-\mathrm{Met}$, Mn-Met supplementation and control group. These results are in line with those obtained by Mousa and EL-Sheikh, (2004) who indicated that addition of 80 and $120 \mathrm{mg}$ zinc sulfate improved total protein and globulin, while it decreased albumin and urea concentration in blood serum of lactating buffaloes.. Spears and Kegley, (2002) stated that there were no differences in plasma $\mathrm{Zn}$ concentrations with zinc methionine- or zinc oxid addition to rations heifers and beef steers. Shakweer et al., (2005) and Shakweer et al., (2006) found normal concentrations of total protein, globulin and zinc with different levels of zinc methionine supplementation.. However, albumin and urea concentrations in blood serum of lactating Friesian cows and growing Friesian calves were decreased. Kincaid et al., (1997) reported that addition of zinc methionine to rations of $6 \mathrm{wk}$ old calves for $6 \mathrm{wk}$ increased the concentrations of zinc, albumin and $\alpha_{2}$-macroglobulin in the serum.

Table (5): Effect of zinc or/and manganese methionine supplementation on blood plasma constituents of lactating buffaloes:

\begin{tabular}{|c|c|c|c|c|c|}
\hline \multirow[b]{2}{*}{ Items } & \multicolumn{4}{|c|}{ Experimental groups } & \multirow[b]{2}{*}{$\begin{array}{c}\text { SE } \\
\pm\end{array}$} \\
\hline & control & $\begin{array}{c}40 \mathrm{mg} \\
\text { Zn-Met/ kg DMI }\end{array}$ & $\begin{array}{c}40 \mathrm{mg} \\
\text { Mn-Met / kg DMI }\end{array}$ & $\begin{array}{c}40 \text { mg Zn-Met + } \\
40 \text { mg Mn-Met / kg DMI }\end{array}$ & \\
\hline $\mid$ Total Protein g/dl & $8.25^{\mathrm{d}}$ & $9.54^{\mathrm{D}}$ & $9.15^{\mathrm{c}}$ & $9.88^{\mathrm{a}}$ & 0.114 \\
\hline Albumin g/dl & $4.45^{\mathrm{c}}$ & $4.95^{\mathrm{a}}$ & $4.63^{b}$ & $5.02^{a}$ & 0.034 \\
\hline Globulin g/dl & $3.80^{c}$ & $4.59^{b}$ & $4.52^{b}$ & $4.86^{\mathrm{a}}$ & 0.074 \\
\hline Urea $\mathrm{mg} / \mathrm{dl}$ & $36.76^{a}$ & $32.60^{\mathrm{b}}$ & $31.22^{\mathrm{b}}$ & $24.92^{c}$ & 0.803 \\
\hline $\mathrm{Zn} \quad \mathrm{mg} / \mathrm{dl}$ & $0.66^{d}$ & $0.80^{\mathrm{b}}$ & $0.69^{c}$ & $0.89^{a}$ & 0.017 \\
\hline $\mathrm{Mn} \mathrm{mg} / \mathrm{dl}$ & $0.23^{\mathrm{b}}$ & $0.19^{c}$ & $0.25^{\mathrm{b}}$ & $0.28^{\mathrm{a}}$ & 0.007 \\
\hline
\end{tabular}

$a, b$, $c$ and $d$ : values in the some row with different superscripts differ significantly $(P<0.05)$. 
Feed intake and feed conversion :

The effect of Zn-Met, Mn-Met and Zn-Met plus Mn-Met supplementation on feed intake and feed conversion of lactating buffaloes are shown in table (6).There were no significant differences in daily feed intake of concentrate feed mixture, berseem hay rice straw and total DM among the different experimental groups because the amounts of the previous times were estimated according to milk yield. Addition of Zn-Met plus Mn-Met resulted in the highest feed intake of TDN and DCP ( 13.34 and 1.67 , respectively) than those of Zn-Met, Mn-Met and control , being (13.11 and 1.67) , (12.90 and 1.56) and (12.61 and 1.41), respectively. These esults are in accordance with those obtained by Bach et al., (2000); Krober et al.,(2000) and Younge et al., (2001) who reported that there was no improvement in dry matter intake when protected amino acids was given to animals. Addition of $\mathrm{Zn}-\mathrm{Met}$ plus Mn-Met ,Zn-Met, Mn-Met and supplementation improved feed conversion expressed as the quantities of DM, TDN and DCP required to produce one $\mathrm{kg} \mathrm{7 \%} \mathrm{FCM} \mathrm{compared} \mathrm{to} \mathrm{that} \mathrm{control} \mathrm{group.} \mathrm{However,} \mathrm{Zn-Met}$ plus $\mathrm{Mn}$-Met supplementation increased significantly $(P<0.05)$ compared to other addition and control group. The quantities of DM. TDN and DCP per/ $\mathrm{kg} 7 \%$ FCM for control group were significantly higher $(P<0.05)$ than those of Zn-Met plus Mn-Met, Mn-Met, Zn-Met supplementation .

Table (6): Effect of zinc or/and manganese methionine supplementation on daily feed intake and feed conversion of lactating buffaloes .

\begin{tabular}{|c|c|c|c|c|c|}
\hline \multirow[b]{2}{*}{ ltems } & \multicolumn{5}{|c|}{ Experimental groups } \\
\hline & Control & $\begin{array}{c}40 \mathrm{mg} \\
\mathrm{Zn}-\mathrm{Met} / \mathrm{kg} \\
\mathrm{DM}\end{array}$ & $\begin{array}{c}40 \text { mg } \\
\text { Mn-Met / kg DMI }\end{array}$ & $\begin{array}{c}40 \text { mg Zn-Met + } \\
40 \text { mg Mn-Met /kg } \\
\text { DMI }\end{array}$ & $\begin{array}{c}\text { SE } \\
\pm \\
\end{array}$ \\
\hline Av. Body weight $(\mathrm{Kg})$ & 561.25 & 568.75 & 568.75 & 562.5 & \\
\hline \multicolumn{6}{|c|}{ Daily Feed Intake (Kg/head/day): } \\
\hline Concentrate Mixture & 8.43 & 8.5 & 8.5 & 8.48 & \\
\hline Berseem hay & 5.65 & 5.73 & 5.73 & 5.65 & \\
\hline Rice straw & 5.65 & 5.73 & 5.73 & 5.65 & \\
\hline \multicolumn{6}{|c|}{ Total Daily Nutrients Intake, $(\mathrm{Kg} /$ head): } \\
\hline DM & 19.73 & 19.95 & 19.95 & 19.78 & \\
\hline TDN & 12.61 & 13.11 & 12.90 & 13.24 & \\
\hline DCP & 1.41 & 1.67 & 1.56 & 1.70 & \\
\hline Av. Milk yield daily $(\mathrm{kg})$ & $5.61^{c}$ & $6.84^{\mathrm{b}}$ & $7.16^{\mathrm{b}}$ & $7.89^{\mathrm{a}}$ & 0.23 \\
\hline Daily 7\% FCM yield (Kg) & $5.43^{c}$ & $6.92^{\mathrm{b}}$ & $7.09^{a b}$ & $7.78^{a}$ & 0.24 \\
\hline $\begin{array}{l}\text { Feed conversion : } \\
\mathrm{kg} \mathrm{DM} / \mathrm{kg} 7 \% \mathrm{FCM}\end{array}$ & $3.65^{\mathrm{a}}$ & $2.90^{\mathrm{b}}$ & $2.86^{\mathrm{b}}$ & $2.62^{c}$ & 0.26 \\
\hline $\mathrm{kg}$ TDN/ kg 7\% FCM & $2.34^{a}$ & $1.91^{\mathrm{b}}$ & $1.85^{\mathrm{b}}$ & $1.75^{\mathrm{c}}$ & 0.15 \\
\hline $\mathrm{kg} \mathrm{DCP} / \mathrm{kg} 7 \%$ FCM & $0.261^{a}$ & $0.240^{\mathrm{ab}}$ & $0.220 .^{b}$ & $0.221^{b}$ & 0.01 \\
\hline
\end{tabular}

These results are in accordance with those obtained by Miller et al., (1989), Olson et al., (1999) and Salama et al., (2003) who reported that dry matter intake7 $\mathrm{kg}$ milk was not affect by zinc addition to lactating cows or goats. Spears et al., (2004) showed that supplementation of Zinc methionine significantly $(P<0.05)$ improved the feed conversion of lambs as feed $(D M)$ compared to control and ZnSO4 groups. Mousa and EL-Sheikh, (2004) 
indicated that the addition of zinc to tested rations did not affect feed intake as (DM, TDN and DCP) and feed efficiency when $40 \mathrm{mg}$ zinc sulfate was added to lactating buffaloes ration. Shakweer et al., (2005) showed that the feed intake as (DM, TDN and DCP) was increased with all different zinc methionine supplementation $(40,80,120 \mathrm{mg} / \mathrm{kg} \mathrm{DMI})$ compared to that of the un-supplemented control group. Daily nutrients intake was improved with addition of 80 and $120 \mathrm{mg}$ zinc methionine compared to either control or control plus $40 \mathrm{mg}$ zinc. Also it was found that feed efficiency was increased with added of 40 and $80 \mathrm{mg}$ zinc methionine levels compared to either $120 \mathrm{mg}$ zinc methionine level or the control group in Friesian dairy cows.

Economic efficiency

Data presented in table (7) showed that the animals fed Zn-Met plus Mn-Met was the best group for give the highest milk yield with the lowest feed cost. Animals fed Mn- Met was better than that fed Zn-Met, which the lowest efficiency was obtained with those fed control ration. The feed cost to give one $\mathrm{kg} 7 \%$ FCM recorded 1.94 , 2.11, 2.14 and 2.65 L.E. with groups fed the previous treatments, respectively. Regarding the relative feed cost , the groups fed both $\mathrm{Zn}$ or $\mathrm{Mn}$ methionine supplementation tended to higher relative feed cost but animals fed the $\mathrm{Zn}$ plus $\mathrm{Mn}$ methionine supplementation was the lowest relative feed cost, as show in table (7).

Table (7): Economical evaluation of the tested group of lactating buffaloes.

\begin{tabular}{|c|c|c|c|c|}
\hline \multirow[b]{2}{*}{ Items } & \multicolumn{4}{|c|}{ Experimental groups } \\
\hline & Control & $\begin{array}{c}40 \mathrm{mg} \\
\text { Zn-Met/ } \\
\text { kgDMI }\end{array}$ & \begin{tabular}{|c|}
$40 \mathrm{mg}$ \\
Mn-Met \\
$/$ kgDMI
\end{tabular} & $\begin{array}{c}40 \mathrm{mg} \mathrm{Zn-Met} \mathrm{+} \\
40 \mathrm{mg} \text { Mn-Met } / \\
\text { kgDMl }\end{array}$ \\
\hline \multicolumn{5}{|l|}{ Intake as fed (Kg/ head/day): } \\
\hline Concentrate Mixture & 8.43 & 8.50 & 8.50 & 8.48 \\
\hline Berseem hay & 5.65 & 5.73 & 5.73 & 5.65 \\
\hline Rice straw & 5.65 & 5.73 & 5.73 & 5.65 \\
\hline Zn-Met* (Biomet Zn) (g/head/day) & --- & 5.3 & ---- & 5.3 \\
\hline Mn-Met*(Bioplex Mn) (g/head/day) & --- & --- & 8.0 & 8.0 \\
\hline $7 \% \mathrm{FCM}$ yield $(\mathrm{Kg} / \mathrm{head} / \text { day })^{1}$ & 5.43 & 6.92 & 7.09 & 7.78 \\
\hline Cost of feed consumed (L.E/day) & 14.40 & 14.83 & 14.96 & 15.13 \\
\hline Cost of $\mathrm{Kg} 7 \%$ FCM (L.E/day) ${ }^{2}$ & 2.65 & 2.14 & 2.11 & 1.94 \\
\hline Relative feed cost $/ \mathrm{Kg} 7 \%$ FCM & 100 & 80.75 & 79.62 & 73.21 \\
\hline
\end{tabular}

1 adjusted $7 \%$ FCM yield.

${ }^{2}$ Cost of Kg 7\% FCM (L.E/day) = Cost of feed consumed / average daily 7\% FCM yield.

Calculation on based of the following price in Egyptian pound (L.E.) per ton at 2008 , the price of one ton (L.E) of concentrate mixture, berseem hay and rice straw were 1075, 845 and 101respectivly; the price of one $\mathrm{Kg}$ from Biomet $\mathrm{Zn}$ and Bioplex Mn were $\mathbf{5 0}$ L.E. , the price of one $\mathrm{kg}$ of milk was $3.5 \mathrm{~L} . \mathrm{E}$.

* Biomet $\mathrm{Zn}$ Bioplex Mn as commercial name

\section{Conclusion:}

From the obtained results, It could be concluded that $\mathrm{Zn}$-Met plus MnMet supplementation could be economically and successfully used for lactating buffaloes to improve digestibility's, feeding values, feed efficiency, milk production and economical efficiency . 


\section{REFERENCES}

A.O.A.C. (1995) . Official Methods of Analysis $15^{\text {th }}$ ed. Association of Official Analytical Chemists. Washington, Virginiall U.S.A.

A.P.R.I. (1997). Animal Production Research Institute ,Animal Nutrition (Scientific and Production), Agriculture Research Center, Ministry of Agriculture , Cairo, Egypt.

Arelovich, H. M., (1998). Effects of zinc and manganese on digestion, ruminal and blood parameters of cattle fed prairie hay. Ph.D. Thesis. Oklahoma State University, Stillwater.

Bach, A.; G.B. Huntington and M.D. Stren (2000). Response of nitrogen mean in preparturient dairy cows to methionine supplementation . J. Anim. Sci., 78: 742.

Basiuoni, M,I; H.M.A. Gaafar; MF,E. Ali; A.A. Shitta and A.Sh.F. Shamas (2009). Utilization of zinc methionine supplementation to lactating Friesian cows 1- productive performance. Egyptian j. Nutrition and Feeds ,12 (3)Special: 1-13

Bruwaene, R.; G. B. Gerber; R. Kirchmann; J. Colard and J. Van Kerkom, (1984). Metabolism of $51 \mathrm{Cr}, 54 \mathrm{Mn}, 59 \mathrm{Fe}$ and $60 \mathrm{Co}$ in lactating dairy cows. Health Phys, 46: 1069-1082.

Cohn, E. J.; FRN. Gurd; D. M. Surgenor; B. A. Branes; R. K. Brown; G. Deroux; I. M. Gillespie; F. W. Kahnt; W. F. Lever; C. H. Liu; D. Mittelman; R. F. Mouton; K. Scbmid and E. Uroma, (1950). A system for the separation of the components of human blood Quantitative procedms for the separation of the protein components of human plasma. J. Am. Chem. Soc, $72: 465$.

Compbell M.H, J.K. Miller and F.N. Schrick, (1999). Effect of additional cobalt, copper, manganese and zinc on reproduction and milk yield of lactating dairy cows receiving bovine somatotropin. J. Dairy Sci., 82:1019-1025.

Curran, G. L., and D. L. Azarnoff, (1961). Effect of certain transition elements on cholesterol biosynthesis. Fed. Proc.,20: 109-111.

Davis, C. D.; D. M. Ney, and J. L. Greger, (1990). Manganese, iron and lipid interactions in rats. J. Nutr. ,120: 507-513.

Duncan, D. B. (1955): The Multiple Range and Multiple F Test. Biometrics, $11 ; 1-42$.

Drupt E., (1974). Colorimetric determination of albumin. Biol. J. 9. 777.

Eadie, J.M., P.N. Hobson and S.O. Mann, (1967). A note on some comparison between the rumen content of barley fed steers and that young calves also fed on high concentrate rations. J. Anim. Prod., 9:247.

Fawcett, J. K., and J. E. Scott (1960). Colorimetric determination of urea. An. J. Clin. Path. B, 156.

Ghoneim, A. (1964). Animal Nutrition. $6^{\text {th }}$ Ed. Anglo-Egyptian Library, Cairo. (Arabic text book).

Gunter,S.A.; E.B. Kegley ; G.C. Duff; D.Vermeire (1999). The performance by steers fed different zinc source before and during receiving at a New mexico feedlot. J. Anim. Sci., 77 (suppl.1).19 (Abstract). 
Haurowitz, F., (1950). Chemistry and Biology of Proteins. Academic Ress, New York.

Hidiroglow, M. (1979) Manganese in ruminant nutrition. Can. J. Anim. Sci., 59: 217-236. Issue.

Kessler, J.; I. Morel; F. A. Dufey; A. Gutzwiller, A. Stern and H. Geyes (2003). Effect of organic zinc sources on performance, zinc status, and carcass, meat, and claw quality in fattening bulls. Livest. Prod. Sci., 81:171-171.

Kincaid, R.L. ; B.P. Chew and J.D. Cronrath, (1997). Zinc oxide and amino acids as sources of dietary zinc for calves: effect on uptake and immunity, J. Dairy Sci., $80: 1381-1388$.

Korber, T.F.; M. Senn; W. Langhhans and F. Sutter (2000) Effect of rumenprotected methionine in low protein ration on metabolic trails and performance of early lactation cows as opposed to rations with elevated crud protein content. Journal of Animal Physiology and Animal Nutrition, 84: 148.

Leach, R. M.; Jr., and E. D. Harris, (1997). Manganese. In: B. L. O'Dell and R. A. Sunde (eds.) Handbook of Nutritionally Essential Mineral Elements. p 335-356. Marcel Dekker Inc., New York.

Ling, E. R. (1963). "Atext Book of Dairy Chemistry". Vol. 11- 3rd Ed. London Chapman and Hall Ltd.

Makino, T.; M. Saito; D. Horiguchi and K. Kina (1982). Colorimetric determination of zinc : Clinica. Chimica. Acta, $120: 127-135$.

Mandal, G.P.; R.S. Dass; D.P. Isore; A.K. Garg and G.C. Ram, (2007). Effect of zinc supplementation from two sources on growth, nutrient utilization and immune response in male crossbred cattle (Bos indicus $\times$ Bos taurus) bulls, Anim. Feed Sci. Technol., 138 . 1-12.

Miles, R. D.; P. R. Henry, (1999). Relative trace mineral bioavailability. In: proceeding of the California Animal Nutrition Conference held on may 6, 1999, Piccadilli Inn Hotels, Fresno, CA, PP. 1- 24.

Miller, J. K.; N. Ramsey and F. C. Madsen, (1989). The trace elements. In The Ruminant Animal. Prentice Hall. D. C. Church (Ed.). p.342, Prentice- Hall, Englewood Cliffs, NJ.

Mousa, Kh. M. M. and S. M. EL-Sheikh, (2004). Effect of different leveles of zinc supplementation on utilization of non-protein nitrogen for lactating buffloes. J. Agric. Sci. Mansoura Univ., 29(6): 3063-3073.

Olson, P. A.; D. R. Brink; D. T. Hickok; M. P. Carlson; N. R. Schneider; G. H. Deutscher; D. C. Adams; D. J. Colburn and A. B. Johnson, (1999). Effects of supplementation of organic and inorganic combinations of copper, cobalt, manganese, and zinc above nutrient requirement levels on postpartum two-year old cows. J. Anim. Sci., 77:522-532.

Ott, E. A., W. H. Smith, R. B. Harrington, H. E. Parker and W. M. Beeson (1966). Zinc toxicity in ruminants. W. Physiological changes in tissues of beef cattle. J. Anim. Sci., 25:432.

Reafat, A. M. and E. S. Saleh, (1962). Derivation two equations for conversion of cows and buffaloes milk production to afat corrected milk first. Conf. Anim. Nut., 203(Feb.)-El-Minia. 
Rulquin, H. and R.Verite (1993). Amino acids of dairy cows : Production effects and animal reguirments In: P.C. Garnsworthy and D.J.A.Cole (Eds). Recent Advances in Animal Nutrition. PP.55. Nottingham University Press, Nottingham.U.K.

Salama Ahmed, A.K.; G. Cajat; E. Albanell; X. Snch and R. Casals, (2003). Effects of dietary supplements of zinc-methionine on milk production, udder health and zinc metabolism in dairy goats, J. Dairy Res. 70 (2003), pp. 9-17.

SAS ,1985. SAS user's guide : statistics .SAS. Inst.,Inc., Cary, NC.

Seymour,W.M.; C.E.Polan and J.H.Herbein(1990). Effect of dietary protein degradability and casein or amino acids in dairy cows. J.Dairy Sci.,73:735.

Shakweer, I. M. E.; A. A. M. EL-Mekass and H. M. EL-Nahas, (2005). Effect of different levels of supplemented organic zinc source on performance of Friesian dairy cows. J. Agric. Sci. Mansoura Univ., 30 (6):3025-3035.

Shakweer, I.M.E. ; A.A.M. EL-Mekass and H.M. EL-Nahas (2006) . Effect of supplemental zinc methionine concentrations on digestibility, feed efficiency and some ruminal and blood parameters and performance of Friesian calves. J. Agric.Sci. Mansoura Univ. 31(8): 4935-4935.

Shakweer, I.M.E. and H.M. EL-Nahas( 2005). Productive performance of suckling calves fed diets supplemented with zinc methionine. J. Agric.Sci. Mansoura Univ. 30(6): 3037-3046.

Socha, M. T.; and A. B. Johanson, (1998). Summary of trials conducted evaluating the effect of a combination of complexed zinc methionine, manganese methionine, capper lysine and cobalt glucoheptonate on lactation and reproductive performance of dairy cattle. J. Dairy Sci., 81 (suppl. 1), 251 (Abstract)

Spears, J. W. ; P. Schlegel; M. C. Seal and K. E. Lloyd, (2004). Bioavailability of zinc from zinc sulfate and different organic zinc sources and their effects on ruminal volatile fatty acid proportions .Livestock Prod.Sci.90:211-217

Spears, J. W. (1996) Organic trace minerals in ruminant nutrition. Anim. Feed Sci. Technol. 58: 151-163.

Spears, J. W. and E. B. Kegley, (2002). Effect of zinc source (zinc oxide vs. zinc proteinate) and level on performance, carcass characteristics, and immune response of growing and finishing steers. J. Anim. Sci., 80:2747-2752.

Van Keulen, J. and B. A. Young (1977). Evaluation of acids insoluble ash as a natural marker in ruminant digestibility studies. J. Anim. Sci., 44; 282.

Weichselboum, F. (1946). Colorimetric determination of total protein. An. J. Clin. Path.., $16: 40$.

Young, B.A.; J.J.Murphy; M.Rath and B.K.Sloan(2001) Effect of dietary absorbable methionine and lysine concentrations of milk production of dairy cows offered grass silage based diets. Irish J. of Agric. and Food Research., $1: 40$ 
Shakweer, I.M.E. et al.

تـاثير إضـافة الزنــك وا أو المنجنيز ميثيـونين على الأداء الاتتـاجى للجـاموس

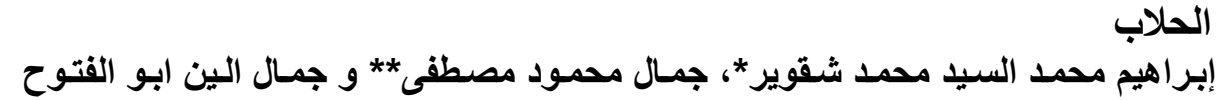

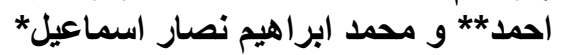

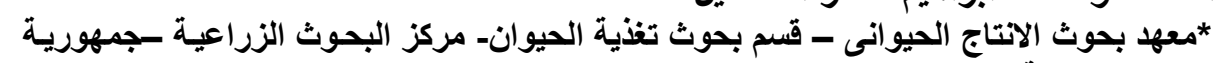

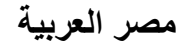
(كلية الزراعة. جامعة الفيوم - جمهورية مصر العربية.

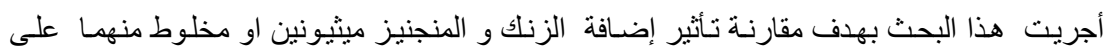

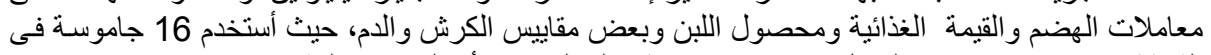

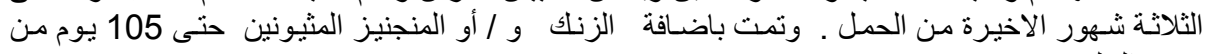

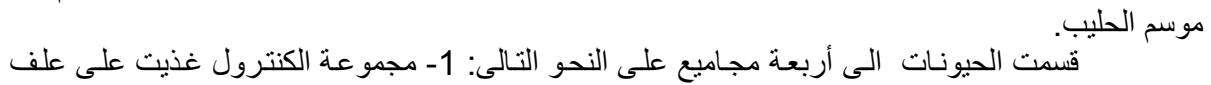

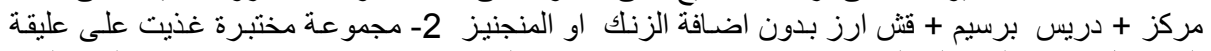

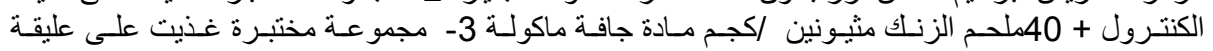

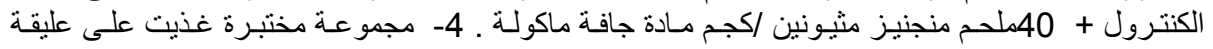
الكتنرول +(40 ملحم زنك مثيونين +40ملحم منجنيز مثيونين) /كجم مـادة جافة ماكولـة وكانت النتائج

إضـافة الزنكلك ومنجنيز مثيونين معا أدى إلى تحسن في معاملات الهضم و القيمة الغذائية للعليقة

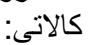

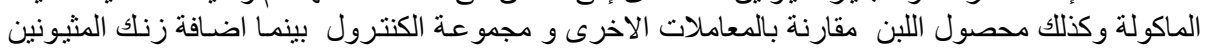

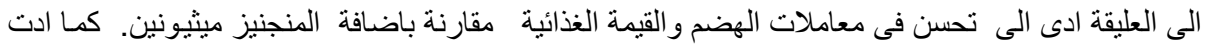

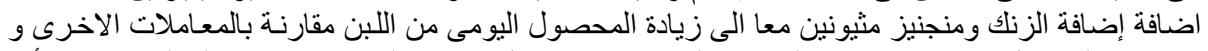

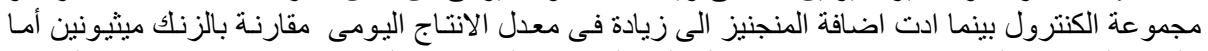

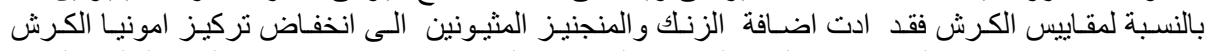

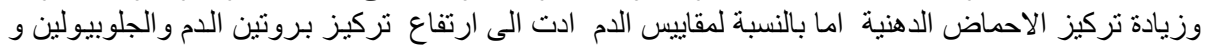

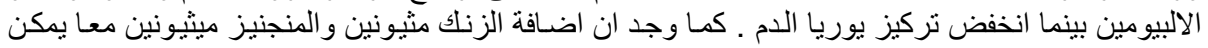

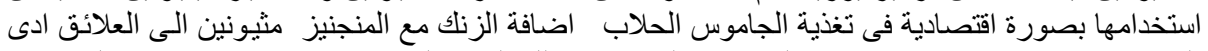

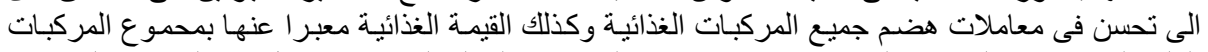

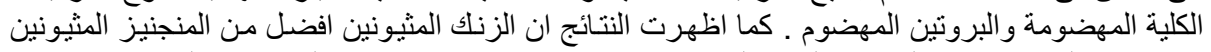

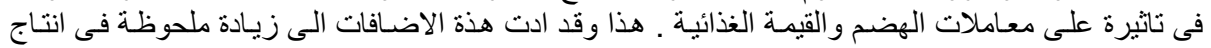

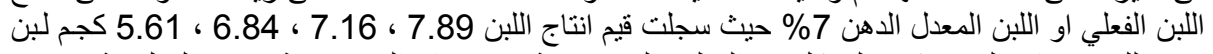

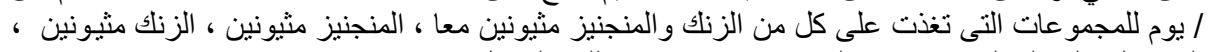

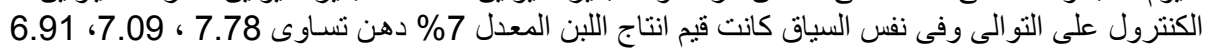

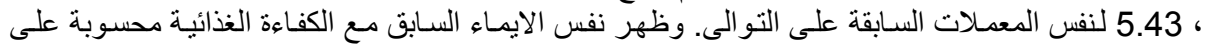

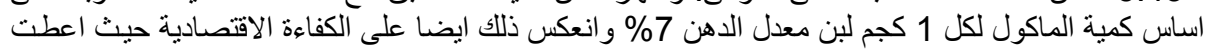

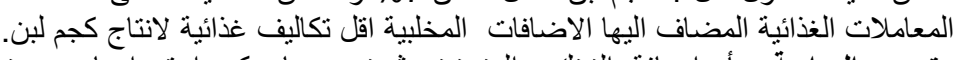

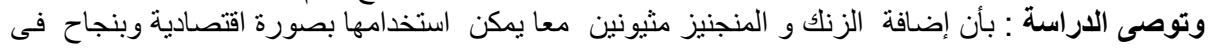

تغذية الجاموس الحلاب لتحسين الهضم و القيم الغذائية ، الكفاءة الغذائية ، انتاج اللبن و الكفاءة الاقتصادية.

كلية الزراعة - جامعة المنصورة مركز البحوث الزراعية قام بتحكيم البحث

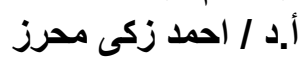
أ.د / كامل عتمان ابراهيم 
J. Animal and Poultry Prod., Mansoura Univ., Vol. 1(11), November, 2010 